\title{
The question of Calvin's involvement in the trial of Servetus at Vienne (1553)
}

\author{
$\mathbf{E} \mathbf{S} \mathbf{R a}^{1}$ \\ (University of Pretoria)
}

\begin{abstract}
\end{abstract}
The question of Calvin's involvement in the trial of Servetus at Vienne (1553)

This article considers the extent of John Calvin's involvement in the trial of Michael Servetus at Vienne (1553). Calvin is held responsible for Servetus' arrest and the accusations against him at the trial of Vienne. During this trial Servetus was convicted of heresy and was burned in effigy, since he had escaped. The letter of de Trie, the period preceding the trial, and the proceedings of the trial of Vienne are looked at to determine whether the allegations of Calvin's unjust involvement in the trial of Vienne are justified. This article contends that Calvin did not play any direct role in the conviction of Servetus at the trial of Vienne.

\section{INTRODUCTION}

Michael Servetus (1509 - 1553), known as a physician, a mathematician, an author, a publisher and a heretic, died on the stake at Champel in Geneva on 27 October 1553. The civil court of Geneva condemned him as a mortal criminal. The verdict contained various quotations from his works, implicating his seditious affairs and his heresy against the doctrine of the Trinity (Calvin, Opera, 829).

Allegations against John Calvin (1509 - 1564), implicating his direct role in the case against Michael Servetus, came to the fore immediately after Servetus' execution. The allegations brought in against Calvin have dominated studies in the case of Michael Servetus. The allegations against Calvin began with Sebastian Castellio $^{2}$ and

1 This article is based on research conducted for a $\mathrm{PhD}$ in Church History, University of Pretoria, submitted under the title: Michael Servetus: the unfortunate and fair conviction as heretic and sedetionary at the trials in Vienne and Geneva, 1553.

2 Castellio is mentioned mainly in English biographers. His family name is Chatillion or Chateillon, but he preferred to be called 'Castellon'. See Buisson (1892:28). He was a professor of Greek at the University of Basel and a school teacher in Geneva under Calvin, and hoped to become office minister. Due to Calvin's refusal to recommend him to the civil council, he expressed both his views and resentment toward Calvin. He wrote a treatise, Concerning Heretics, Whether They Are to Be Persecuted under the name of Martin Bellius in 1544, but he only gained disrepute. 
Camillo Renato ${ }^{3}$ shortly after Servetus' execution. Castellio, who was banished from Geneva in 1544, accused Calvin of intolerance. Castellio wrote in several pamphlets, especially De Haereticis an sint persequendi, which was published under the alias Martin Bellius. He stood up for Servetus and condemned Calvin for lacking Christian sympathy. A year after Servetus' death in September 1554, Camillo Renato, an Italian Anabaptist writer, wrote an indictment in his book Carmen against Calvin, claiming that the act of burning Servetus was cruel and unchristian. ${ }^{4}$ Such accusations were raised in earnest again on the 350th anniversary of Servetus' trial. The accusations rest on the presupposition that Calvin had a major influence on the Council and the government of Geneva. However, it is also possible to distinguish in Servetus' writings a personal hatred towards Calvin. Those who criticise Calvin, usually quote Servetus' statements or testimonies made during the trial at Geneva.

However, the accusations against Calvin are at variance with each other, are often ignorant of the actual facts, and the spirit of the age in question, and tend to be influenced by sentiment.

Though the accusations against Calvin use both trials of 1553 as sources, and the trial of Geneva is more controversial, this article focuses on the trial of Vienne. There are a few assumptions implicating Calvin that are derived from the Roman Catholic inquisition in Vienne. The first assumption that slanders Calvin is that he handed over the final evidence to de Trie in order for him to convey it. It is believed that Calvin was deceiving in using de Trie in disguise.

This article asks the question: Was Michael Servetus accused by Calvin in the trial of Vienne? Two supporting questions are also considered: What were the letters of de Trie about? What was the trial like? The correspondence between de Trie and his cousin as well as the court proceedings of the Vienne trial are considered in order to answer these questions.

For Sebastian Castellio, see Bainton (1951:25-79). For Castellio's points on Calvin's role in the case against Servetus see Simpler (da:145); \& Bainton (1963:177). For Zweig's defending sympathetically in favour of Servetus see Zweig (1936).

3 Camillo Renato (c. 1500-?1575) , who was an originator of Italian Anabaptists, stood against Calvin. For more details on him, see Williams (1972:170-1 180 185-7 passim).

4 Camillo Renato, "Carmen", in Tedeschi (1965: 187). It was published in Traona on the first anniversary of Servetus' execution. But it is criticised that it was mingled "biblical and mythological allusions in a highly mannered humanistic Latin." (176). It is also contained in Calvin's Opera (vol. XV, 236-45). 


\section{CORRESPONDENCE OF DE TRIE}

The publication of Servetus' book, Christianismi Restitutio, led the Roman Catholic leaders to arrest and condemn him in the town of Vienne. Before looking at the allegations, it is important to understand what happened before and during the arrest in Vienne and the significance of de Trie's correspondence.

The Cardinal of Vienne, François de Tournon, was elected the Lieutenant General for religion in south-eastern France. He was a strict Roman Catholic and persecuted reformers, innovators, and heretics (Willis 1877:239). He "was responsible for the murder of thousands of Valdensians and Albigensians during the many years of his rule" (Hillar 1997:265). Matthieu Ory, the Roman who was to become inquisitor of France, was not only trained by de Tournon, who called him from Rome, but "penitentiary of the Apostolic See, and general inquisitor of the kingdom of France and all Gale" (Audin 1850:429). Servetus was living in their territory and would suffer under them.

A copy of Christianismi Restitutio fell into the hands of Guillaume de Trie (Macdonell 1983:131). ${ }^{5}$ He was a close friend of Calvin, and was living in Geneva as a converted Protestant. De Trie had been a sheriff and a French noble in Lyon before moving to Geneva in 1549 and becoming a member of the Council of Two Hundred. ${ }^{6}$ While living in Geneva, his cousin, Antoine Arneys, an ardent Catholic, corresponded with him, hoping to persuade him to return to Roman Catholicism. Considering de Trie's letter of February 26, 1553, it can be seen that Arneys criticised "the lack of church discipline and order at Geneva, and the general abuse of liberty among Protestants" (Wilbur 1972:151). De Trie clarifies the matter, saying that the Genevan church was consistently based on the Word of God and had better discipline than the Roman Catholic Church. As an example, he informs him of Servetus' presence in Vienne. De Trie also tells his cousin about Servetus' heresy. The letter was enclosed with the first eight pages of Servetus' book, Christianismi Restitutio (title page, contents, and the first four pages) (Opera, 835-8, Hillar 1997:271-2, Willis 1877:236-8).

Instead of providing an answer in the letter why he should not return to the Roman Catholic Church, de Trie mentions how the Roman Catholic Church was lay in the matter of the heretic in their midst. De Trie accuses Servetus of being a certain heretic who should be burned alive. Servetus calls the Trinity a three-head watchdog, Cerberus, Jesus

5 De Trie was surprised that the Roman Catholic authorities of France "tolerated such a blasphemer as its author, Servetus" (Killen 1843:10).

6 "He was son-in-law of Guillaume de Budé, the noted French humanist and founder of the Collège de France" (Wilbur 1972:150). 
Christ an idol, and infant baptism a diabolical invention. He divulges Michael Servetus' real name, that he was using an alias, Villeneuve, and that he came from Spain. Just as his cousin attacked the reformed church of Geneva, so de Trie was embarrassing the Roman Church.

Arneys passed the letter from his cousin, along with the pages of Servetus' book, to the authorities of Lyon. De Trie's letter was thus the direct, unsuspecting, cause of Servetus' arrest, having unconsciously supplied information to the court, revealing who Servetus was, what he had done, and where he lived. Arneys divulged "that this was not only a detestable heresy, but that it tended to subvert Christianity itself" (Ford 1860:50). One of the authorities conveyed the letter and attachments to the inquisitor of Lyon, the Dominican friar, Matthieu Ory, and to Bautier, vicar-general, who immediately proceeded with the case.

Ory wrote a letter to a subordinate of Cardinal Tournon, sieur de Villars on March 12, 1553. In the letter he asked him to act secretly on the writings (Opera, 838-9, Hillar 1997:274). The subordinate of the Cardinal, de Villars, sent for the vicar-general of Lyon, Bautier and Louis Arzellier, the vicar-general of Archbishop of Vienne, asking for a meeting to proceed on the issue. They determined to proceed with the case secretly after a long conference. They sent a letter on March 15, 1553 to Monsieur de Maugiron, the Lieutenant General ${ }^{7}$ of the Dauphiné, who commissioned Arzellier to investigate the case (Opera, 839-40, Hillar 1997:274-5).

In order to provide all the evidence to the Royal Prospector, Bautier, the vicar-general of Lyon collected Ory's letter, the letter of Cardinal de Tournon, along with the four pages of the Christianismi Restitutio. On March 16, 1553 Louis Arzellier and Anthony de la Court, Vice Bailiff, of de Maugiron, called upon the Peyrollier, chief official. The Royal Prospector, Bautier, gave him his deposition, saying therein that a certain Michael Servetus, also called Villeneuve, should be detained in Vienne. Furthermore it was expressed that Ory had examined the heretical four pages, and that the Cardinal de Tournon appraised Monsieur de Maugiron to treat this case with secrecy and promptness (Audin 1850: 438-9).

The judges were ordered to meet at the house of Monsieur de Maugiron. Simultaneously, Louis Arzellier, the vicar-general, and Anthony de la Court, the Vice Bailiff, and the secretary of Monsieur de Maugiron, the lieutenant general of the Dauphiné, sent a message to Michel de Villeneuve, that they had something important to say to him. They informed him that they had been suspecting him of heresy and

7 Its functions "were military, political, administrative, and, on special occasions, judicial also" (Guizot 1868:n. 1, 305). 
ordered him to destroy all his books, documents, and notes. When he was summoned before the Inquisition of Vienne, Servetus, using the name Villeneuve, "replied that he had lived long in Vienne, was on good terms with the clergy and professor of theology, and had never until now been suspected of heresy" (Willis 1877:243). They gave him two hours to appear and this gave him enough time to destroy all suspicious evidence - books, documents, and notes (Opera, 749). Then Servetus allowed Louis Arzellier, Anthony de la Court, and the secretary of Monsieur de Maugiron to search his room. Although they searched his lodging, it was in vain. ${ }^{8}$ They could not connect Michel de Villeneuve to Servetus.

The next day, on March 17, the judges summoned the corrector, Guéroult, instead of Arnoullet, the printer, who at that time was on business at Toulouse. They asked Guéroult what sort of books they had printed during the past eighteen months. He denied all charges, and after some long interrogations they could not gain sufficient evidence from him. They searched his house and the printing house, but with no success. The servants and their families in the employment of Arnoullet were examined next to no avail. Even the workmen of the printing house and their families denied that the four leaves shown to them had been printed there.

The following day, on March 18, Arnoullet, who had returned from Toulouse, was instantly summoned to appear before the judges. $\mathrm{He}$ denied that he had printed the pages. "The material supplied did not yet satisfy the inquisitor, because there was no proof that Villanovanus was Servetus, nor that he was the author of the Restitutio" (Bainton 1953: 157). The judges queried Pierre Palmier about Servetus, his physician, but he had no idea of his book or identity, except his name and profession and suggested that Ory travel to Vienne. Palmier invited Ory to discuss the heresy issue and they agreed on the need for more evidence against the physician Villeneuve.

Ory, the inquisitor of Lyon, did not give up the investigation, but demanded that Arneys submit the complete book, which was with his cousin in Geneva. Arneys informed de Trie of this request, ${ }^{9}$ De Trie was surprised by the letter of inquiry and must have been confused. He asked Calvin for the complete copy, but Calvin not only refused, but also could not give it to him. Calvin had earlier sent it to Peter Viret in Lausanne two years previous (Opera, 843). On March 30, de Trie wrote a third

8 They could only find two copies of Apologetica Disceptatio pro Astrologia. See Hillar (1997:275) \& Mattison (1991:31).

9 Willis (1877:245), Mackinnon (1962:138) \& Bainton (1953:156) suggest that Ory dictated the letter to Arneys. Unfortunately, it was not extant. 
letter, enclosing a copy of Calvin's book Institutio Religionis Christianae, which had Servetus' notes written in the margins.

De Trie forwarded several autographed letters of Servetus on March 26 (Opera, 840-2, Hillar 1997:275-6). De Trie was surprised that the private correspondences had gone so far. He never intended for his personal letter to be used to arrest Servetus.

It has been argued that Calvin handed the two dozen letters of Servetus which were crucial evidence in the trial of Vienne over to de Trie in spite of the confidentiality between Calvin and Servetus (Dyer 1850:317-8). ${ }^{10}$ Porter sharply criticises Calvin for providing pages 421424 of De Baptismo with the letters (Porter 1854:13). However, Calvin did not break the confidentiality without permission. The reluctantly sent published letters were not confidential. Besides, the letters conveyed were sent to Calvin after he had requested to terminate the communication with Servetus. Calvin did not divulge that the author of the heretical book, Christianismi Restitutio, was Servetus or Villeneuve, even though he had published the copy that had been given to Calvin seven years earlier. Calvin also knew that he was in Vienne. It is hard to believe that he was bent on disclosing his identity. He did not intend to reveal the author at all (Killen 1843:12).

Another allegation states that de Trie was not the author of his letters, but Calvin. Willis asserts that Calvin, as the supposed author of the letters, dictated them on the assumption that de Trie had shown him his letters (Willis 1877:235-8). Wright also imagines that "Trie communicated Arney's letters to Calvin, who dictated answers to them ... Mr. D'Artigny, who published them from originals, calls them, Calvin's letters under the name of William Trie. By the means of this de Trie, Calvin raised a persecution against Servetus at Vienne" (Wright 1806: 132). ${ }^{11}$

The detailed intrinsic nature of the debate implying Calvin's authorship is well illustrated in Dyer (1850:314) who considers the allegation $^{12}$ that de Trie's letter was written at Calvin's dictation and then published it under de Trie's name. Dyer (ibid) mentions that de Trie

10 Dyer (1850:317-8) introduces some information in the letters in his book and is in favour of Calvin. But Porter (1854:13) stands against Calvin, exactly introducing the number of letters sent by Servetus as twenty-seven.

11 See also Tulloch (1860:138-9) who also speculates on Calvin's possible authorship.

12 Abbé d'Artigny first found letters of de Trie and texts of the trial of Servetus at Vienne from the Records of the Court in the archives of Vienne in 1749 before the French Revolution on November 21, 1793. He contends that Calvin took materials for Servetus' life from the undoubted archives of the Archbishop of Vienne. See Drummond (1848:31-2). 
may have written the letter without Calvin's knowledge, though he is of the opinion that Calvin "at least aided and abetted" the inquisition.

De Trie started the private correspondence with his cousin Arneys. It is highly improbable that Calvin dictated de Trie's private letter out of personal hatred and to revenge him. De Trie did not require Calvin's aid. He was a French noble, intelligent, and a member of the Council of Two Hundred. There is no physical proof that Calvin dictated the letter. Nobody can prove the dictation, except with great presumptions. This is based on the fact that de Trie was a close friend of Calvin, and knew that Calvin knew Servetus' identity.

As Cunningham (1989:322) says, Calvin willingly did what he believed and thought was lawful but did not hide like Servetus. This is why Guizot (1868:308-9) clearly concludes that the allegations were without proof and are vain as well as erroneous.

Such conjectures result from the premature judgement that Calvin was the direct cause of Servetus' exposure by providing the crucial evidence to the Roman inquisitor. Bolsec argues that Calvin wrote a letter to the Cardinal of Vienne, François de Tournon, to report that Servetus was Villeneuve. Castellio also contends that Calvin informed the Cardinal Tournon, who "went through Geneva on September 19, 1552," that Servetus should be burned because he was a heretic (Castellio 1935:n., 38, 283; see Opera, vol. XIV, 355). In addition, Wallace alleges that the proofs accusing Servetus were found in the writings of De la Roche, Allowerden, Mosheim, Bock, and Trechsel (Wallace, d.a.:433). Cunningham (1989:324) discharges the allegation against Calvin because of insufficient evidence in all the accounts.

Allwoerden (1772:45-6) also argues this allegation, but admits that there is no proof. ${ }^{13}$ Tulloch, who stands against Calvin, admits: "The special blame of Calvin in the whole matter is very much dependent upon the view we take of his previous relation to the accusation and trial of Servetus by the Inquisition at Vienne, but there is no satisfactory evidence" (Tulloch 1860:139). They do not have any direct testimony to prove their assumptions. They are the imaginations that may possibly come from Servetus' petitions at the trial of Geneva, in which he boldly insults Calvin without logical explanation. Cunningham (1989:322; Gibbon 1932, 314) writes against the allegations saying:

"Calvin was mainly or largely influenced by personal and vindictive feelings towards Servetus, is destitute of all proof or even

13 Allwoerden (1772:45) quotes Bolsec's assumption in the footnote: "In vita CALVINI cap, III. p. 8.: Nam omnes postea modes perueftiganuit (scilicet CAVINIUS) quibus homini nocere, necemque procurare posset, et scripsit idcirco ad Reuerend. Dominium Cardinalem TURNONIUM...." 
plausibility. There is no ground to believe, or even to suspect, that Calvin was connected with originating or instigating the proceeding, which ultimately led to Servetus' apprehension by the popish authorities at Vienne."

Calvin makes it clear in his Opera that he was not responsible, denying the accusation that he supplied materials to the Roman Catholic inquisitor in order to destroy Servetus (Opera, 479, Willis 1877:502-3).

\section{THE TRIAL IN VIENNE}

On April 4, 1553, Matthieu Ory, the inquisitor general, submitted the material to de Tournon: ${ }^{14} \mathrm{a}$ few pages of Calvin's Institutio; several of Servetus' autographed letters to Calvin; and further evidence, based on de Trie's latest information. De Tournon summoned a conference with the archbishop of Vienne, Palmier, at the cardinal's palace Château in Rossillon. He sent for the inquisitor Ory, Arzellier, the ecclesiastics, and theologians of the church. The evidence, including the letters of de Trie, two dozen letters of Servetus to Calvin, and a few pages of Christianismi Restitutio with Servetus' notes, was sufficient to lead to imprisonment of Villeneuve, known as Servetus, and his printer, Arnoullet.

The archbishops of Vienne and Lyon agreed to arrest them. On returning back to Vienne in the evening, Palmier, and his vicar, Arzellier, called Anthony de la Court, ${ }^{15}$ vice bailiff, to the archbishop's palace. In compliance with the command, de la Court arrested the printer, Arnoullet, and ordered him to bring the latest copy of the New Testament to his palace. Knowing that Servetus was attending on Madam de Montgiron, de la Court informed him that there were wounded and sick prisoners in the palace of Dauphiné. While visiting the prison, Servetus was told about the charge of heresy against him and was locked up immediately. De la Court allowed Servetus his servant, Benoit Perrin, as well as other visitors (Opera, 844-5; Wallace, d.a.:434; \& Willis 1877: 254).

\subsection{The First Interrogation}

The next day, April 5, the first interrogation against him ${ }^{16}$ was announced in Vienne. The Archbishop Palmier sent for the inquisitor general, Ory, to open the interrogation, notifying him that the judges had confined Villeneuve and his printer. The trial took place in the evening and was presided over by Ory (Bainton 1953:159-60, Opera, 844-5).

\footnotetext{
${ }^{14}$ He was the cardinal at the Chateaux de Rossillon near Vienne.

${ }^{15} \mathrm{He}$ was a friend of Servetus (Ford 1860:54).

${ }^{16}$ It is recorded in Opera, 844-7.
} 
After taking the oath, Servetus gave a brief account of his life. He omitted all references to his interactions with the reformers and gave no acknowledgement of knowing any theological writings. ${ }^{17} \mathrm{He}$ initially claimed to be Michel de Villeneuve, aged forty-two, a medical doctor, and that he came from Tudéla of Navare (Opera, 845). He confessed that he had left Spain twenty-seven or eight years previous, and served under Quintana, the confessor of the emperor, at the age of fifteen or sixteen. He continued, stating that, after serving Quintana, he had gone to Paris where he entered the Collège de Calvi and the Collège de Lombards, majoring in mathematics. Afterwards he went to Lyon and Avignon, but left at once, staying for two or three years in Charlieu, practising his medical skill. He then lived in the house of the archbishop, Pierre Palmier, in Vienne. He acknowledged that he had printed Leonhardum Fuchsium in defensio apologetica pro Symphoriano Campeggio (1536), Syropporum Universa Ratio (1537), and had commentated on Ptolemy's Geography (1535 and 1541) (Opera, 846). He swore that he had never printed any other book besides these. He boldly tried to prevent himself from being identified with Servetus. He denied that he had lived in Toulouse, where he had been known under his real name. Despite pretending that he was not the author of the heretical book, it was difficult to deceive the inquisitor.

What could he say when the inquisitor showed him pages 421-424 of De Baptismo, with angry marginal notes? (Opera, 847, 849). The inquisitor then asked him several questions about infant baptism (Opera, 846-7, Willis 1877:256-7): How would infants be saved and overcome Adam's sin without their regeneration? His answers to the question did not satisfy them. His knowledge of infant baptism and his handwriting convinced the inquisitors that he was the author. Soon it became apparent that he had to succumb under the weight of the obvious evidence. In the end he admitted that it might have been his handwriting. The inquisitors had found some evidence for heresy in his writings, and decided to report them for the attention of the Church (Dyer 1850:320).

After examining his answers in the first interrogation, the court of the inquisition charged him as "a persistent liar" (Odhner 1910:23), and had proof that he was an Anabaptist.

17 It is likely that the initial trial of Vienne focused on Servetus' personal life rather than his theological views (Osler 1909:16). 


\subsection{Second Interrogation}

For the second interrogation on April 6, 1553, Servetus again swore to tell the truth on the Gospels. ${ }^{18}$ When Servetus noticed that two dozen letters from him to Calvin were before the inquisitors, he lost all courage and in order to free himself from the dilemma, invented a falsehood.

The inquisitors asked him the first question based on epistle xv (Opera, 848, Willis 1877:258), asking how he understood a proposition concerning the Living Faith and the Dead Faith, Mori autem sensim dictur in nobis Fides quando tolluntur vestimenta - "now faith dies perceptibly in us when its vestments are thrown off". Servetus answered that he believed the vestments of faith to be works of charity and mercy [vestmenta fidei sunt Opera charitatis et virtutis.]

The second question was how he understood Free Will - De libero arbitrio, coming from epistle xvi. Shedding tears he lied although he swore that he was telling the truth - Messieurs ie vous veulx dire la verité (Opera, 848-9,. Bainton 1953, 160-1; see Henry 1849:189-90). In his answer, in which he avoided a direct answer, he claimed that he did not know where Servetus came from. He looked like Servetus; and acted like Servetus in disguise. According to him, Calvin mistook him for Servetus. The confessions were full of untruths and bold-faced lies. Although he tried to make it clear to the inquisitors that Villeneuve and Servetus were two different persons, he was soon revealed as the heretic Michael Servetus and the author not only of the heretical books, De Trinitatis Erroribus and Dialogorum de Trinitate libri Duo but also of a third book, Christianismi Restitutio.

The third question was on Infant Baptism, and was based on epistle xvii. This letter was about infants, mere fleshy beings, that were incapable of receiving the gift of the Spirit - "Parvuli carnis non erant capaces doni spiritus" (Opera, 849). It was nothing new compared to the last question. When asked the meaning of this sentence, Servetus replied that they were unable to receive the gift of the Holy Spirit.

The fourth question from epistle xviii, regarding the Trinity and the Generation of the Son of God - "de Trinitate et generatione Filii Dei", "Was," he said, "written in the midst of discussions with Calvin" (Opera, 849). The fifth question was, "de carne Christi glorificata, quae absorbetur a gloria divinitatis," - of the glorified body of Christ that was carried out of the Glory of the Deity - more fully than it was at the Transfiguration (Opera, 849). Although Servetus thought he presented his opinions well to them, his judges regarded him as a cunning liar. $\mathrm{He}$

18 “... lequel apres le serment par luy faict sur les Sainctes Evangeles de dire la verité, a esté par nous interrogé comme s'ensuyt." The second interrogation was recorded in Opera (847-9). 
did not admit to the identified heresies in these writings, but only to what his judges and the church would approve (Opera, 849). Eventually he confessed that the writings were his. After hearing his confession the inquisitors adjourned the interrogation until the next day.

Realising how at risk he was, Servetus resolved to escape. He asked the grand prior to send for his servant, Perrin, to get 300 écus from the monastery at St. Pierre. An hour earlier, Ory had ordered the guard to forbid any one from talking to Servetus. However, the cell door of the prison had been left open. Servetus had been free in the prison and was treated with consideration and respect (Dyer 1850:319). ${ }^{19}$ During that evening he pretended to take a walk in the garden, searching for a way of escape.

\subsection{Escape and Third Interrogation}

On April 7, 1553 he was up at four o'clock, early in the morning and escaped through a window. During the previous day's walk he found a terrace overlooking the courtyard of the palace. He asked the unsuspecting jailer for the key to the garden so that he could take a walk. The Jailer did not suspect him as he was dressed in a bathrobe. Servetus was fully dressed underneath. He went up to the terrace, jumped over to the courtyard, and reached the Rhône River outside. At about 9 o'clock he was outside Vienne, according to his own confession later at the trial of Geneva (Bainton 1953:160-1 \& Gaberel 1858: vol. II:248.). The jailer's wife was the first to discover his escape, two hours later. She felt that her life was in danger, and thus tore her hair, and beat her children, servants and the other prisoners. The authorities reported the escape, and ordered the town gate be shut down and guarded, but it was too late.

Despite Servetus' escape the third interrogation (Opera, n., 850-3) against him and his printer, Arnoullet, proceeded. The trial took ten weeks of examining his books and his letters to Calvin. Ory collected new information about the place that printed the books. Thus Ory, Anthony de la Court, and Arzellier met three workmen - Jean du Bois, Calude Papillion, and Thomas de Straton - who confessed that they had printed Christianismi Restitutio They were not aware of the heretical doctrines in the book, because it had been written in Latin (Opera, n., 852). Straton, one of the workers, revealed that Villeneuve had covered the cost of printing with his own money and had dispatched five bales of the printed books to Pierre Merrin at Lyon (Opera, n., 853).

19 Guizot (1868:311) tells us that a daughter of Anthony de la Court, Vice Bailiff, was cured by Servetus and he then became one of his friends. Monsieur de Maugiron was another friend. 
Ory and Arzellier hurried off to Lyon to examine Merrin. He admitted that he had received five bales of books from Michel de Villeneuve of Vienne through a priest of Vienne, a certain Jacques Charmier. He confessed that he did not know the contents of the book. They ordered him to unpack the packages and took them to the palace of the archbishop at Vienne. Ory and Arzellier met with Charmier in Vienne and put him into prison for three years because of his friendship with Villeneuve. Ory then convinced the judges that the Christianismi Restitutio, printed secretly in Vienne, was heretical. Servetus was found guilty of heresy and of threatening public peace. The inquisitors were witnesses to these crimes, as they themselves had heard Servetus' denials and confessions. The civil tribunal added to the sentence a fine of a thousand livres to be given to the king Dauphiné from whose prison Servetus had escaped. The sentence, containing the names of the inquisitors, was read on June 17, 1553 (Opera, 784-7, Allwoerden, 1727:55-7, Wright 1806:148-51):

At noon of the same day Servetus was slowly burnt publicly in effigy by a fire built by Françis Berodi, the executioner, at de Charnève along with the five bales of Christianismi Restitutio found at Lyon (Mackinnon 1962:141; Wright 1806:151-2). Any book of his found was to be burnt. Arnoullet was confined in the prison for four months, but because he made it appear that Guéroult assured him that Christianismi Restitutio was a harmless book, and that he did not know Latin, he was set free to go to Lyon. Guéroult saved himself by fleeing to Geneva, and became involved in the fraction of Geneva (Henry 1849:191). The rest of the investigation was continued through until Saturday the 23rd, two days before Christmas 1553 .

There are no official records on Servetus' escape until his arrest at Geneva, three months and six days later. Guizot thinks that Servetus was wandering about near Vienne until the verdict appeared on June 17, after which he tried to find a safe haven in France or Switzerland (Guizot 1868:311).

\section{CONCLUSION}

It has been indicated that the trial of Vienne resulted from the letters de Trie sent to his cousin, Arney, in 1553. Although this correspondence was originally private, they were used in implicating Servetus of being a heretic. In assessing Calvin's involvement, note should be made of de Trie's second letter. In this letter he expresses his surprise that his private letters are being used in public to accuse Servetus. It is recognised that de Trie stated his intention ironically in it.

In the trial of Geneva, on the contrary, Servetus accused Calvin of divulged him to the Roman Catholic Church. Several assumptions con- 
cerning the trial of Vienne could be ascribed to Servetus' imagination and hatred for Calvin. At the trial of Vienne the Roman Catholic inquisitors were interested in the heretic, and found information to this effect in the correspondence between de Trie and Arney.

It must therefore be concluded that Servetus' rial at Vienne resulted from personal correspondence between de Trie and Arney, and never had anything to do with Calvin. One fact rests against Cavin, though, where he was unwilling to give evidence against Servetus to de Trie. Thus, Calvin had no involvement in the trial of Vienne.

\section{Consulted literature}

Allwoerden, H Ad 1727. Historia Michaelis Serveti. Helmstedt: Stanno. Bucholtziano.

Audin, J M V 1850. History of the life, works, and doctrines of John Calvin. Translated by J McGill. Louisville: B. J. Webb and Brother.

Bainton, R H 1951. "Sebastian Castellio, champion of religious liberty", in: R H Bainton, B Becker, M Valkhoff, and S van der Woude (eds). Castellioniana: Quatre Études sur Sébastien Castellion et L'idée de la Tolérance. Leiden: E. J. Brill, 25-79.

-, 1953. Hunted Heretic: The life and death of Michael Servetus 1511-1553. Boston: Beacon Press.

-, 1963. "Interpretations of the Reformation" in: Studies on the Reformation. Boston: Beacon Press, 104-116.

Buisson, F E 1892. Sebastien Castellio. Sa vie et son oeuvre (1515-1563). Etude sur les origins du prostestantisme liberal francais. Tom 1. Paris: Hachette.

Calvin, J 1962. Institutes of the Christian Religion. J T McNeill (ed), Translated by F L Battles. The Library of Christian Classics. Vol. XX, XXI. Philadelphia: Westminster Press.

-, 1964. Ioannis Calvini Opera quae supersunt omnia. G Baum, E Cuntiz, \& E Reuss (eds) Vol. VIII. New York: Johnson Reprint Corporation.

-, 1975. John Calvin, Selections from His Writings. John Dillenberger (ed). Missoula: Scholar Press.

-, 1858. Letters of John Calvin. J Bonnet (ed). Translated by D Constable. 4 Vols. Philadelphia: Presbyterian Board of Publication.

-, 1947. "Calvinist comeback?" in: Time, 24 February 1947, 78.

Castellio, S 1935. "Reply to Calvin's book in which he endeavors to shows that heretics should be coerced by the right of the sword", in: R H. Bainton (ed), Concerning heretics, whether they are to be persecuted and how they are to be treated. A collection of the opinions of learned men both ancient and modern. New York: Colombia University Press, 265-87.

Cunningham, W 1989. The Reformation and the theology of the Reformation. Edinburgh: Banner of Truth Trust.

Drummond, W H 1848. The life of Michael Servetus, the Spanish physician, who, for the alleged crime of heresy, was entrapped, imprisoned, and burned by John Calvin the Reformer, in the city of Geneva, October, 27, 1553. London: John Chapman.

Dyer, T H 1850. The Life of John Calvin. London: Bradbury \& Evans. 
Emerton, E 1909. "Calvin and Servetus." in: Harvard Theological Review 2, April 1909: 139-160.

Ford, S H 1860. Migual Servede, the hero-martyr of the sixteenth century. St. Louis: St. Louis Baptist Publishing Co.

Gaberel, J 1858. Historie de L'église de Genève depuis Le Commencement de la Réformation Jusqu'a Nos. 3 Vols. Genève: Joël Cherbuliez.

Gibbon, E 1932. The decline and fall of the Roman Empire. Vol. III. New York: Modern Library 1932.

Guizot, M [1868]. Saint Louis and Calvin. Philadelphia: Lippincott.

Henry, S 1849. The life and times of John Calvin, the great reformer. Vol. II. Translated by P Henry. London: Whittaker.

Hillar, M 1997. The case of Michael Servetus (1511-1553): The turning point in the struggle for freedom of conscience. Lewiston: Edwin Mellen Press.

Killen, W D 1843. The Unitarian martyr - a defence of John Calvin in the case of Michael Servetus. Belfast: William M'Comb.

Lindsay, T M 1908. A history of the Reformation. Vol. II. Edinburgh: T \& T Clark.

Macdonell, J 1983. Historical trials. R W Lee (ed). Littleton: Fred B Rothman \& Co.

Mackinnon, J. 1962. Calvin and the Reformation. New York: Russell \& Russell.

Odhner, C T 1910. Michael Servetus, his life and teachings. Philadelphia: J B. Lippincott.

Osler, W 1909. Michael Servetus. Baltimore: Lord Baltimore Press.

Porter, S J 1854. Letter to the Rev. William D. Killen, D. D. on his defence of John Calvin, in the Case of Michael Servetus. London: Edward T. Whitfield.

Renato, C 1965. "Carmen", in: J A Tedeschi (ed), Italian Reformation studies in honor of Laelius Socinus. Translated by D Rounds. Firenze: Felice Le Monnier 185-95.

Rilliet, J H A 1846. Calvin and Servetus: the reformer's share in the trial of Michael Servetus, historically ascertained. Translated by W K Tweedie. Edinburgh: John Johnstone.

Servetus, M 1966. Christianismi Restitutio. Lugduni:1553. Frankfurt: Unveränderter Nachdruck.

-, 1989 "Ptolemy's Geography. 1535", in: Christianismi Restitutio and Other Writings (Transl by C D O'Malley). Birmingham: Classics of Medicine Library, 15-37.

Simpler, S H d.a. Roland H. Bainton: An examination of his Reformation historiography. Lewiston: Edwin Mellen Press.

Tulloch, J 1860. Leaders of the Reformation: Luther, Calvin, Latimer, Knox, the representative men of Germany, France, England and Scotland. Boston: Gould \& Lincoln.

Wallace, $\mathrm{R}$ d.a. Antitrinitarian biography, or sketches of the lives and writings of distinguished Antitrinitatians: Exhibiting a view of the state of the Unitarian doctrine and worship in the principal nations of Europe, from the Reformation to the close of the seventeenth century: To which is prefixed a history of Unitarianism in England during the same period. Vol I. London: E T Whitfield.

Williams, G H 1972. "The two social strands in Italian Anabaptism", in: Buck L P \& Zophy J W (eds), The social history of the Reformation. Columbus: Ohio State University Press, 156-207. 
Willis, R 1877. Servetus and Calvin: A study of an important epoch in the early history of the Reformation. London: Henry S. Kings.

Wright, R 1806. An apology for Dr Mchael Servetus: Including an account of his life, persecution, writings and opinions: Being designed to eradicate bigotry and uncharitableness: and to promote liberality of sentiment among Christians. Wisbech: F.B. Wright.

Zweig, S 1936. The right to heresy, Castellio against Calvin. Translated by E \& C Paul. New York: The Viking Press. 